(C) 2020, The Authors. Published by FASS Inc. and Elsevier Inc. on behalf of the American Dairy Science Association ${ }^{\circledR}$. This is an open access article under the CC BY-NC-ND license (http://creativecommons.org/licenses/by-nc-nd/4.0/).

\title{
Temporal, spatial, and management variability in the carbon footprint of New Zealand milk
}

\author{
S. F. Ledgard, ${ }^{1 *} \odot$ S. J. Falconer, ${ }^{1} \oplus$ R. Abercrombie, ${ }^{2}$ G. Philip, ${ }^{2}$ and J. P. Hill ${ }^{2,3}$ () \\ ${ }^{1} \mathrm{AgResearch}$ Ruakura Research Centre, Hamilton, New Zealand, 3214 \\ ${ }^{2}$ Fonterra Co-operative Group and Fonterra Research and Development Centre, Private Bag 11-029 Palmerston North, New Zealand, 4472 \\ ${ }^{3}$ Riddett Institute, Massey University, Private Bag 11-222 Palmerston North, New Zealand, 4442
}

\begin{abstract}
The carbon footprint of milk from year-round grazedpasture dairy systems and its variability has had limited research. The objective of this study was to determine temporal, regional, and farm system variability in the carbon footprint of milk from New Zealand (NZ) average dairy production. Farm production and input data were collected from a national database for 2010/11 to 2017/18 across regions of NZ and weighted on relative production supplied to the major dairy cooperative Fonterra to produce an NZ-average. Total greenhouse gas emissions were calculated using a life cycle assessment methodology for the cradle-to-farm gate, covering all on- and off-farm contributing sources. The NZ-average carbon footprint of milk varied from 0.81 $\mathrm{kg}$ of $\mathrm{CO}_{2}$ equivalent $\left(\mathrm{CO}_{2} \mathrm{eq}\right) / \mathrm{kg}$ of fat- and proteincorrected milk (FPCM) in 2010/11 (with widespread drought) to 0.75 to $0.78 \mathrm{~kg}$ of $\mathrm{CO}_{2} \mathrm{eq} / \mathrm{kg}$ of $\mathrm{FPCM}$ in $2013 / 14$ to $2017 / 18$, with a trend for a small decrease over time. Regional variation occurred with highest carbon footprint values for the Northland region due to greatest climatic and soil limitations on pasture production. Dairy cattle diet was approximately $85 \%$ from grazed pasture with up to $15 \%$ from brought-in feeds (mainly forages and by-products). The $\mathrm{CO}_{2}$ emissions from direct fuel and electricity use constituted $<2 \%$ of total $\mathrm{CO}_{2}$ eq emissions, whereas enteric methane was near $70 \%$ of the total. An estimate of potential contribution from direct land use change (plantation forest to pasture) was $0.13 \mathrm{~kg}$ of $\mathrm{CO}_{2} \mathrm{eq} / \mathrm{kg}$ of FPCM. This was not included because nationally there has been a net increase in forest land and a decrease in pasture land over the last 20 yr. Data used were highly representative, as evident by the same estimated carbon footprint from 368 farms (in 2017/18) from the national database compared with that from a direct survey of 7,146
\end{abstract}

Received June 27, 2019.

Accepted September 13, 2019.

*Corresponding author: stewart.ledgard@agresearch.co.nz farms. New Zealand-specific nitrous oxide emission factors were used, based on many validated field trials and as used in the NZ greenhouse gas inventory, resulting in an 18\% lower carbon footprint than if default Intergovernmental Panel on Climate Change factors had been used. Evaluation of the upper and lower quartiles of farms based on per-cow milk production $(6,044$ vs. $3,542 \mathrm{~kg}$ of $\mathrm{FPCM} / \mathrm{cow}$ ) showed a $15 \%$ lower carbon footprint for the upper quartile of farms, illustrating the potential for further decrease in carbon footprint with improved farm management practices.

Key words: carbon footprint, pasture, milk, life cycle assessment

\section{INTRODUCTION}

Emissions of greenhouse gases (GHG) are of global concern due to impacts on climate change (IPCC, 2013), and total food production is a significant contributor to global GHG emissions ( $>20 \%$ of total; e.g., Vermeulen et al., 2012). Milk from dairy cow production produces an important component of global food protein at 4 to $19 \%$ of the total depending on region and contains a range of other essential nutrients (FAO, 2019). Dairy production also produces a significant component of meat protein production.

The total GHG emissions associated with food production through the supply chain to consumers are typically determined using life cycle assessment (LCA). This aims to capture all GHG emissions, including those from the extraction of raw materials and production of inputs used through all stages of the life cycle (ISO, 2006).

Identification of the carbon footprint per unit of product consumed, in principle, allows the consumer to make choices between products if they wish to limit their environmental footprint associated with their food consumption practices. However, several methodological issues need to be considered for this to be an appropriate practice. Climate change is only one environmental impact and studies on the LCA of products including a range of environmental impact indicators are increasing 
(e.g., for the European Commission Product Environmental Footprinting initiative with up to 15 indicators; EDA, 2018). Dairy has an even broader range of mainly positive attributes when considering all areas of sustainability (Hill, 2017). Nevertheless, climate change is of such importance that it is often the primary focus of product environmental studies.

A second key methodological issue, which is currently receiving greater attention, is the appropriate functional unit. Most studies report the carbon footprint per unit (e.g., kg) of final product. However, the nutritional composition of products and their importance for human nutritional requirements are important and particularly so for a food such as milk, which provides a rich source of a range of nutrients including calcium, vitamins $\mathrm{B}_{2}$ and $\mathrm{B}_{12}, \mathrm{EAA}$, and lipids (Foroutan et al., 2019). Two key constituents are the energy and protein content of the product and most dairy studies now use fat- and protein-corrected milk (FPCM) so that results are compared on a common energy and protein basis (IDF, 2015). It is recognized that specific types of energy and protein can also be important for human nutrition, but this is difficult to quantify and various studies are currently examining different approaches to deal with this (e.g., Ertl et al., 2016; Stylianou et al., 2016). In this paper, we will limit analysis to FPCM.

Research on the carbon footprint of dairy production and consumption through the whole life cycle have generally shown that the dominant contributor is the cradle-to-farm-gate stage [e.g., representing $72 \%$ of the total carbon footprint of US milk through to consumers (Thoma et al., 2013)]. Thus, many studies have focused on the cradle-to-farm-gate stage only. Most of these have been on dairy production in the Northern Hemisphere, where dairy cows are housed indoors for part or all of the year and are fed on crops and by-products harvested and transported to the house (reviewed by Baldini et al., 2017). However, interest is increasing in milk production from cows that spend all year outdoors grazing pasture, which Benbrook et al. (2018) attributed to its more "natural" practice, better milk fatty acid composition, and perceived health and cow-welfare benefits (Benbrook et al., 2018).

In temperate regions of several Southern Hemisphere countries, dairy farm systems are primarily based on year-round grazing of pastures, but limited data are available on the carbon footprint of milk from these countries. One of these countries is New Zealand (NZ), which is the world's largest exporter of dairy products. New Zealand relies on a relatively low-input system of grazing of perennial grass/clover pastures (Clark et al., 2007) and has very high renewable electricity generation (85\% in 2016; MBIE, 2018), which means it has low $\mathrm{CO}_{2}$ emissions from fossil fuel and electricity use. Most published research on the carbon footprint of milk has been on case study farms with relatively few providing data that are representative for a country or major dairy producer. In the United States, Thoma et al. (2013b) presented results based on a survey of 536 farms nationwide, but these were from part- or full-housing systems. Similarly, Gollnow et al. (2014) published results from a survey of 139 farms across several regions of Australia, where cows are grazed outdoors, but for a single year. However, a literature search showed no studies where annual data on the carbon footprint of milk have been regularly assessed over a period of time. Capper et al. (2009) made an estimate of the carbon footprint of milk in the United States based on characteristic production practices for 1944 and 2007 and indicated a significant reduction for 2007, associated with increased productivity per cow and improved production practices. There is a need to better understand how current dairying practices are trending, as production is increasing to meet the global demand for milk, and the opportunities for further reduction in the carbon footprint of milk.

Valid comparison of results from carbon footprint studies requires use of a common methodology (IDF, 2015) and the Livestock Environmental Assessment and Performance partnership (FAO, 2016) have published guidelines for this for dairy production. Most recent studies have generally adhered to these guidelines, in relation to key aspects such as functional unit and allocation methodology. However, there are limited studies where methodology implications have been examined, including the importance of representativeness of farms used in their research.

In this research, the carbon footprint of milk produced across NZ and supplied to the major dairy cooperative Fonterra (which processed over $80 \%$ of all NZ milk) was determined. The objectives were to evaluate the variation in the average carbon footprint of milk over time, between regions of NZ, with differences in cow productivity, and some effects of methodology.

\section{MATERIALS AND METHODS}

\section{Goal, Scope, and Functional Unit}

The goal of the study was to look at the trend over time of the cradle-to-farm-gate carbon footprint of Fonterra milk using attributional LCA methodology. The carbon footprint was calculated for Fonterra's NZ (weighted average) milk, determined using regional milk production data.

The functional unit was $1 \mathrm{~kg}$ of FPCM as determined using the equation recommended by the International Dairy Federation (IDF, 2015). 


\section{System Boundary}

The system boundaries covered from cradle-to-farmgate and included all the inputs needed to produce milk on-farm and the emissions associated with those inputs (Figure 1). This encompassed production of milk onfarm, including on-farm pasture production and utilization (thus determining $\mathrm{CH}_{4}$ and $\mathrm{N}_{2} \mathrm{O}$ from animals), use of farm equipment (representing diesel and petrol), and milk extraction, farm dairy effluent management, and water supply (determining electricity use). Production and delivery of inputs to crop and pasture (e.g., fertilizers, seeds, pesticides) and the production of brought-in and farm-made supplementary feed were also included. Off-farm pasture production for the dairy cow replacements (typically reared off farm) and the pasture production used in wintering-off of nonlactating ("dry") cows were covered as well.

\section{Allocation}

The GHG emissions associated with production of the co-products milk and meat were allocated according to a biological causality, based on the physiological feed requirements of the animal to produce milk and meat (calf, culled cows), using the IDF (2015) methodology. For other processes generating more than one product such as brought-in feed, an economic allocation was used (IDF, 2015). For palm kernel expeller (PKE), this was based on 5-yr average economic data from the World Trade Atlas (for NZ imports from Malaysia and Indonesia; https://www.tradestatistics.com/index .cfm).

\section{On-Farm Inventory Data}

Data Sources. The NZ dairy statistics for all farms (DairyNZ/LIC, 2018) and regional DairyNZ DairyBase (https://www.dairynz.co.nz/business/dairybase/) data from DairyNZ (the NZ industry good dairy research and extension organization) based on a large survey of farms across NZ were the 2 main sources of data used to design a non-overlapping range of regional average estimates. Cow numbers, milk production, milk quality, and size of farms were derived from DairyNZ/LIC statistics, whereas replacement rate, cow weight, and specific data on cows off farm during winter and key input data such as fertilizer nutrients and feed supplements were obtained from the regional DairyBase database (Table 1; varying between 200 and 460 farms/year). All results were calculated for the main regions and multiplied by regional milk collection data from Fonterra to calculate a weighted average for their NZ average milk production. In addition, individual farm data for 2017/18 were collected directly from 7,146 Fonterra farmers across all NZ supply regions during farm visits.

Replacement Animals and Off-Farm Wintering of Animals. In NZ, most replacement animals are reared to weaning on farm and then grazed off farm (Holmes et al., 2002), whereas off-farm wintering of cows varies between regions. Regional data on times of animals off-farm were derived from DairyBase. An average pastoral farm was assumed to be used for grazing replacements and cow wintering off farm. This was based on data for a typical beef and sheep intensivefinishing farm, which also graze dairy replacements (Beef+LambNZ, 2018). This farm relied on clover/

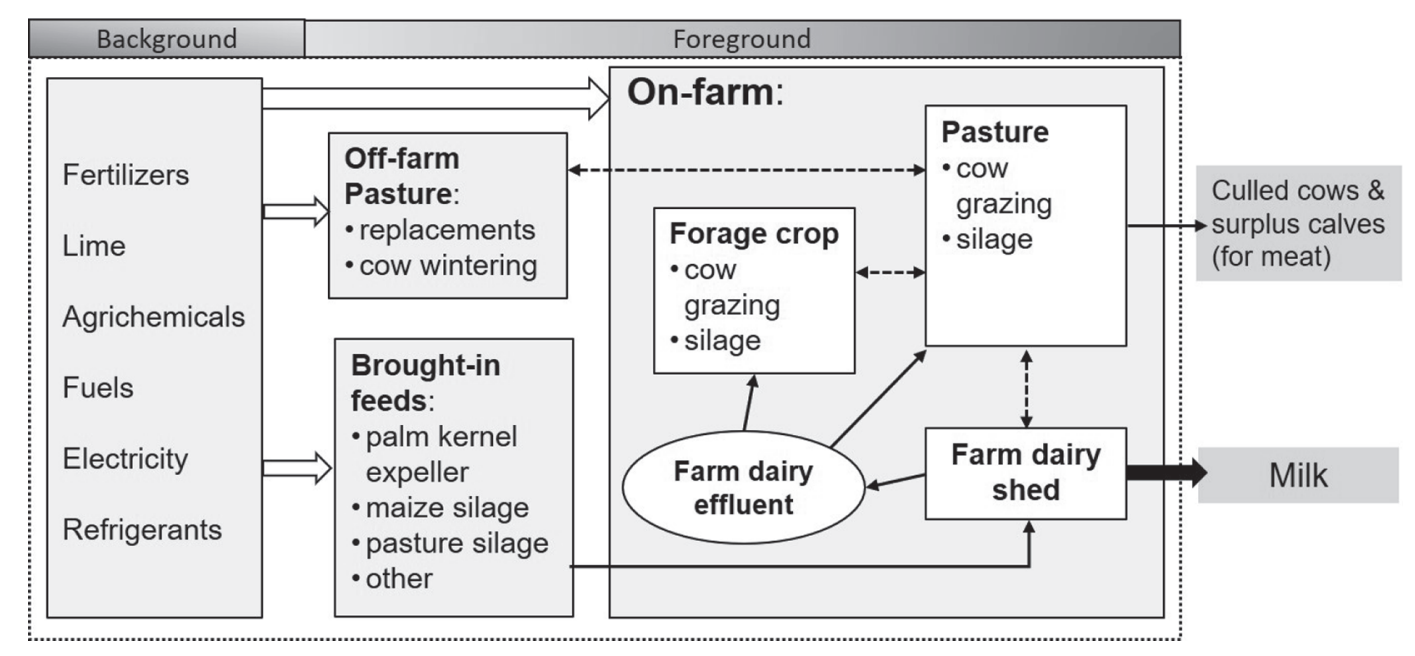

Figure 1. System boundary of the cradle-to-farm-gate study of the New Zealand dairy system based on year-round grazing of pastures, including on-farm, off-farm, and background processes. Dashed lines are animal flows. 
grass pasture for all feeding (all excreta returned via grazing), with production of $7.56 \mathrm{t}$ of $\mathrm{DM} /$ ha and $15 \%$ area for silage production and use. Farm inputs of N, P, $\mathrm{K}$, and lime were $15,25,15$, and $100 \mathrm{~kg} / \mathrm{ha}$ in 2017/18. Replacements were assumed to be transported to this off-farm area after weaning (80-100 kg of live weight, varying with breed and region) and reared to $90 \%$ mature weight (422 $\mathrm{kg}$ in 2017/18) before returning back to the farm at 22 mo of age. Replacement numbers were derived from replacement rate data (Table 1). The feed intake by these replacement animals was calculated using the NZ Inventory model of energy requirements and average data on the monthly feed quality of pasture (MfE, 2018). Average annual DMI for 0- to 1- and 1- to 2-yr-old replacement heifers for 2017/18 was 1,050 and $1,972 \mathrm{~kg} / \mathrm{ha}$, respectively.

Where cow wintering off farm occurred (e.g., for about $8 \mathrm{wk}$ ), it was assumed to be on pasture, except for Otago/Southland where it was assumed to be on a brassica crop (a widespread practice due to cold winter conditions). The distances for transportation of animals grazed off farm were based on a survey of consulting officers from DairyNZ and PGG Wrightson (from multiple locations). All transport and other input emission factors (EF) are given in Appendix Table A1.

Fertilizers. The carbon footprint calculations for the manufacturing and delivery of fertilizers (Appendix Table A1) were based on the NZ study of Ledgard et al. (2011). Data on the distances of fertilizer transportation for each region were provided by experts from the 2 major farmer-cooperative fertilizer companies operating in NZ (Ballance Agri-Nutrients and Ravensdown Limited, Tauranga, Christchurch, New Zealand).
Supplementary Feeds. For PKE (a by-product of the palm oil industry), the carbon footprint was calculated using data from Schmidt (2007) for importation from Malaysia and Indonesia using Harmonised Trade import data from NZStatistics (StatsNZ, 2019). This also accounted for land use change (LUC) using the Blonk Direct Land Use Assessment Tool (Blonk, 2017) and all transportation stages including shipping to NZ.

The GHG emissions from maize silage production in NZ were calculated based on LCA of crops using typical regional production yield and input data from Pioneer (the main NZ maize grain company) and the NZ Foundation for Arable Research (Ledgard and Falconer, 2015). See Appendix Table A1 for EF for all feeds. Transportation distances for brought-in supplementary feeds were obtained from Pioneer experts and DairyNZ farm consultants.

For the small component of on-farm forage crops (10 ha for the average NZ farm in 2017/18), all inputs were accounted for, as well as inputs for renewal back into perennial pasture and the associated crop residue emissions.

Fuel Use. The fuel consumption for all agricultural components, including cow management, pasture production, supplementary feed production, and delivery, was calculated from the analysis of all single operations (e.g., cultivation, agrichemical application, harvesting, and so on, with fuel use from Wells, 2001) needed specifically for each activity from DairyBase data and parameterized in our LCA model (SimaPro Version 8.5, PRé Sustainability, Amersfoort, the Netherlands). The inventory for crude oil included the different origins of oil used in NZ according to the New Zealand Refining

Table 1. New Zealand (NZ) average data on dairy farm production and inputs (per on-farm ha) for 2010/11 to 2017/18 years

\begin{tabular}{|c|c|c|c|c|c|c|c|c|}
\hline Item & $2010 / 11$ & 2011/12 & $2012 / 13$ & $20213 / 14$ & $2014 / 15$ & $2015 / 16$ & $2016 / 17$ & $2017 / 18$ \\
\hline Cow live weight ( $\mathrm{kg} / \mathrm{cow}$ ) & 460 & 482 & 469 & 465 & 468 & 467 & 466 & 469 \\
\hline Lactating dairy cows (cows/ha) & 2.85 & 2.91 & 2.99 & 2.95 & 2.96 & 2.93 & 2.90 & 2.94 \\
\hline Milk solids ( $\mathrm{kg} / \mathrm{ha})$ & 952 & 1,058 & 1,036 & 1,095 & 1,116 & 1,091 & 1,111 & 1,088 \\
\hline $\mathrm{FPCM}^{1}(\mathrm{~kg} / \mathrm{ha})$ & 12,457 & 13,803 & 13.528 & 14,271 & 14,522 & 14,192 & 14,420 & 14,144 \\
\hline Milk fat (\% mass/mass) & 4.79 & 4.83 & 4.80 & 4.84 & 4.86 & 4.86 & 4.86 & 4.83 \\
\hline Fertilizer P (kg/ha) & 31 & 29 & 24 & 29 & 24 & 20 & 27 & 26 \\
\hline Maize silage (kg of $\mathrm{DM} / \mathrm{ha})$ & 479 & 462 & 539 & 506 & 427 & 376 & 401 & 395 \\
\hline Pasture silage ( $\mathrm{kg}$ of DM/ha) & 400 & 503 & 568 & 569 & 495 & 426 & 503 & 547 \\
\hline Barley grain (kg of DM/ha) & 124 & 179 & 226 & 44 & 204 & 160 & 136 & 149 \\
\hline Concentrate ( $\mathrm{kg}$ of $\mathrm{DM} / \mathrm{ha})$ & 38 & 20 & 82 & 62 & 69 & 32 & 64 & 89 \\
\hline Palm kernel expeller ( $\mathrm{kg}$ of $\mathrm{DM} / \mathrm{ha}$ ) & 919 & 780 & 874 & 984 & 1,011 & 916 & 809 & 1,127 \\
\hline Molasses (kg of DM/ha) & 21 & 30 & 27 & 39 & 43 & 29 & 26 & 24 \\
\hline
\end{tabular}

${ }^{1}$ Fat- and protein-corrected milk to a standard of $4.0 \%$ fat and $3.3 \%$ true protein (IDF, 2015).

${ }^{2}$ Other feeds included waste fruit and vegetables (kiwifruit, carrots, and potatoes) and broll (wheat flour by-product). 
Company annual report (2003-2017) and was used in determining the fuel GHG emissions, including extraction, refining, and combustion (Appendix Table A1).

Electricity. Electricity consumption was calculated as a function of cow numbers based on an NZ study by Sims et al. (2005) and as a function of irrigation based on a summary of types of irrigation systems, depth of irrigation water applied, and typical depth of pumping. The NZ electricity inventory was based on the breakdown between different NZ electricity sources (hydro, geothermal, wind, and thermal, including coal, natural gas, and oil; MBIE, 2018) giving an average of $0.274 \mathrm{~kg}$ of $\mathrm{CO}_{2}$ equivalent $(\mathbf{e q}) / \mathrm{kWh}$.

\section{DMI and Nitrogen Excretion}

The animal feed intake model used was the Tier 2 method of the NZ GHG Inventory (MfE, 2018). This is a comprehensive model that operates on a monthly time step and uses data on livestock numbers, livestock performance, BW (Table 1; predominantly Friesian $\times$ Jersey cross), and diet quality. Dry matter intake was estimated by calculating the energy required for lactation, maintenance, growth, gestation, and activity (MJ of $\mathrm{ME}$ per day) and dividing this value by the energy concentration of the diet consumed (MJ of ME per $\mathrm{kg}$ of DM). The model is based on validated algorithms from "Feeding standards for Australian livestock: Ruminants" (CSIRO, 1990), which accounts for the energy requirements of grazing animals.

Data on the brought-in feeds were adjusted for feed wastage (10\% for grain, $15 \%$ for PKE and molasses, and 20\% for silages; DairyNZ, 2017) and NZ average feed quality data to determine the amounts of DMI from feeds. The difference between the total animal energy requirements and that from brought-in feeds consumed was then used to calculate the energy de- rived from pasture. The latter was then divided by the average monthly ME concentration of pasture based on published data (MfE, 2018).

The amount of $\mathrm{N}$ intake by animals was calculated from the DMI multiplied by the $\mathrm{N}$ concentration of the diet and the $\mathrm{N}$ excreted was calculated from $\mathrm{N}$ intake minus $\mathrm{N}$ output in milk (from protein content in Table 1) and meat products $(3.26 \% \mathrm{~N}$ in live weight, based on the NZ GHG Inventory). For all brought-in feed sources, $\mathrm{N}$ concentrations were based on the mean of samples submitted to NZ laboratories and reported by DairyNZ (2017). For pastures, the N concentration was the average NZ pasture $\mathrm{N}$ concentration (from a review of data for the NZ GHG Inventory; MfE, 2018). Of the $\mathrm{N}$ excreted, $95 \%$ was assumed to be applied onto pastures during grazing and 5\% to go through a manure management system as farm dairy effluent (MfE, 2018).

\section{Greenhouse Gas Emissions}

The inventory of GHG emissions covering $\mathrm{CH}_{4}$ from enteric fermentation by cows, $\mathrm{CH}_{4}$, and $\mathrm{N}_{2} \mathrm{O}$ from excreta deposited on pasture and from effluents, and $\mathrm{CO}_{2}$ emissions from lime and urea application were based on Intergovernmental Panel on Climate Change (IPCC) and NZ GHG Inventory methodologies (IPCC, 2006; Table 2, MfE, 2018).

Methane Emissions. Methane emissions from enteric fermentation were calculated from the product of energy and DMI by animals using the NZ GHG Inventory model and the NZ EF (Table 2). Methane emissions from dung and the manure management system were calculated by multiplying fecal DM (from $100-\%$ digestibility of feed) by specific EF from IPCC (2006) according to MfE (2018).

Nitrous Oxide Emissions. Direct $\mathrm{N}_{2} \mathrm{O}$ emissions were calculated by multiplying $\mathrm{N}$ inputs by NZ-specific

Table 2. Key emission factors (EF) and parameters from the New Zealand greenhouse gas inventory (MfE, 2018)

\begin{tabular}{|c|c|}
\hline Process & Mean \\
\hline $\mathrm{kg}$ of $\mathrm{CH}_{4}$ emitted per $\mathrm{t}$ of $\mathrm{DM}$ ingested & 21.6 \\
\hline \multicolumn{2}{|l|}{$\mathrm{kg}$ of $\mathrm{N}_{2} \mathrm{O}-\mathrm{N}$ emitted per $\mathrm{kg}$ of $\mathrm{N}$ applied } \\
\hline Due to urea-N fertilizer use $\left(\mathrm{EF}_{1-\mathrm{UREA}}\right)$ & 0.0059 \\
\hline Due to urine deposited during grazing $\left(\mathrm{EF}_{3 \text { (PRP-URINE) }}\right)$ & 0.01 \\
\hline Due to dung deposited during grazing $\left(\mathrm{EF}_{3 \text { (PRP-DUNG) }}\right)$ & 0.0025 \\
\hline Due to atmospheric deposition of $\mathrm{NH}_{3}\left(\mathrm{EF}_{4}\right)$ & $0.01^{1}$ \\
\hline Due to leaching and runoff of $\mathrm{NO}_{3}^{-}\left(\mathrm{EF}_{5}\right)$ & $0.0075^{1}$ \\
\hline Due to cattle manure applied to soil ( $\left.\mathrm{EF}_{1 \text {-DAIRY }}\right)$ & 0.0025 \\
\hline $\mathrm{kg}$ of $\mathrm{NO}_{3}{ }^{-} \mathrm{N}$ emitted per $\mathrm{kg}$ of $\mathrm{N}$ excreted or $\mathrm{N}$ fertilizer applied $\left(\mathrm{FRAC}_{\mathrm{LEACH}}\right)$ & 0.07 \\
\hline $\mathrm{kg}$ of $\mathrm{NH}_{3}-\mathrm{N}$ emitted per $\mathrm{kg}$ of $\mathrm{N}$ excreted $\left(\mathrm{FRAC} \mathrm{GASM}_{\mathrm{G}}\right)$ & $0.10^{1}$ \\
\hline $\mathrm{kg}$ of $\mathrm{NH}_{3}-\mathrm{N}$ emitted per $\mathrm{kg}$ of $\mathrm{N}$ fertilizer applied $\left(\mathrm{FRAC}_{\mathrm{GASF}}\right)$ & $0.10^{1}$ \\
\hline $\mathrm{kg}$ of $\mathrm{NH}_{3}-\mathrm{N}$ emitted per $\mathrm{kg}$ of $\mathrm{N}$ stored in an anaerobic lagoon $\left(\mathrm{FRAC}_{\mathrm{GASMS}}\right)$ & $0.35^{1}$ \\
\hline
\end{tabular}

${ }^{1}$ Same as IPCC (2006) default values. 
EF corresponding to the fraction emitted to the atmosphere as $\mathrm{N}_{2} \mathrm{O}$ (Table 2). In particular, the NZ emission factor for $\mathrm{N}_{2} \mathrm{O}$ from urine- $\mathrm{N}$ and dung- $\mathrm{N}$ on grazed pasture are 1 and $0.25 \%$, respectively (MfE, 2018), compared with a default emission factor of $2 \%$ for the IPCC methodology (IPCC, 2006). Considerable research effort has gone into establishing country-specific values for these EF (e.g., de Klein et al., 2003), as well as for urea fertilizer and farm dairy effluent applied to pasture (van der Weerden et al., 2016). This reflects the preference noted in method guidelines for use of validated country-specific factors (IDF, 2015; FAO, 2016). These NZ EF were reviewed by international experts certified by the United Nations Framework Convention on Climate Change and are imbedded in the NZ GHG Inventory.

Indirect $\mathrm{N}_{2} \mathrm{O}$ emissions were calculated using the $\mathrm{NZ}$ Inventory $\mathrm{N}$ source and $\mathrm{EF}$, which were developed from research and reviews carried out by NZ scientists and are the same as the IPCC (2006) default values. Key $\mathrm{EF}$ and parameters from the NZ GHG Inventory are summarized in Table 2.

$\mathrm{CO}_{2}$ Emissions from Lime and Urea Application. Direct $\mathrm{CO}_{2}$ emissions from lime $(0.41 \mathrm{~kg} / \mathrm{kg}$; accounting for impurity) and urea $(0.733 \mathrm{~kg} / \mathrm{kg})$ application to soils were calculated according to the default IPCC EF (IPCC, 2006). The $\mathrm{CO}_{2}$ absorbed by plants was not accounted for, since it was assumed to be in equilibrium with losses from the grazing cycle and plant respiration.

\section{Direct Land Use Change}

Direct LUC was calculated based on methodology in PAS2050 (2011), which accounted for changes over a $20-y r$ period. This required adjustment for land converted from forest to dairying over a 20-yr period up to the year of estimation of the carbon footprint. This was based on satellite data from MfE on the change in total area of land conversion from forest, which is regularly updated. It was assumed that $70 \%$ of this conversion was to dairying (all to pasture), based on the average from deforestation surveys of intended land use that varied over time (between 54 and 91\%; Manley, 2017 and corresponding earlier annual reports). The NZ GHG Inventory factor for forestry-to-pasture of $941 \mathrm{t}$ of $\mathrm{CO}_{2} /$ ha was used (MfE, 2018), which included the small increase in soil $\mathrm{C}$ after conversion to pasture (data provided by Ministry for Primary Industries). No LUC was assumed before the year 2000 and the highest LUC occurred in the years 2005 to 2007. It is important to note that the conversion of forest to farmland and associated deforestation was plantation forests and not native forest or bush.

\section{Life Cycle Impact Assessment}

The GHG emissions and carbon footprint were calculated according to IPCC (2013) in kilograms of $\mathrm{CO}_{2}$ equivalent ( $\mathrm{kg}$ of $\mathrm{CO}_{2} \mathrm{eq}$ ). This used global warming potential (GWP) factors for a 100-yr time horizon $\left(\mathbf{G W P}_{\mathbf{1 0 0}}\right)$ of $\mathrm{CO}_{2} 1, \mathrm{~N}_{2} \mathrm{O} 265$, biogenic $\mathrm{CH}_{4} 27.75$, and fossil $\mathrm{CH}_{4} 30.5$.

\section{RESULTS}

\section{Carbon Footprint of Milk}

The annual average carbon footprint of milk $(0.75-$ $0.81 \mathrm{~kg}$ of $\mathrm{CO}_{2} \mathrm{eq} / \mathrm{kg}$ of FPCM; Table 3 ) was dominated by animal-related biogenic $\mathrm{CH}_{4}$ at 69 to $71 \%$ of total $\mathrm{CO}_{2}$-equivalent emissions. Of this component, 85 to $86 \%$ was from enteric $\mathrm{CH}_{4}$ from dairy cows and 12 to $13 \%$ from enteric $\mathrm{CH}_{4}$ from replacement animals, while dung/manure $\mathrm{CH}_{4}$ was only 1 to $2 \% \cdot \mathrm{N}_{2} \mathrm{O}$ emissions from soil constituted 15 to $16 \%$ of total $\mathrm{CO}_{2}$-equivalent emissions, of which 61 to $63 \%$ was from on-farm excreta and 20 to $21 \%$ from $\mathrm{N}$ fertilizer applied on farm. Emissions of $\mathrm{CO}_{2}$ made up 14 to $15 \%$ of the carbon footprint, with the dominant contributors being from production of supplementary feeds for dairy cows (from on and off farm) and $\mathrm{N}$ fertilizer production. Feed production for animals off-farm, non-N-fertilizer production, lime, and electricity each contributed about 4 to $12 \%$ of total $\mathrm{CO}_{2}$ emissions, whereas fuel (mainly diesel) use on farm was only 3 to $4 \%$. The $\mathrm{CO}_{2}$-equivalent emissions from pesticides and refrigerant loss were negligible.

\section{Temporal Changes in Production and Farm Inputs}

Stocking rate on farm increased during the first 3 yr from 2010/11 to 2012/13 and thereafter fluctuated between 2.9 and 3.0 cows/ha (Figure 2). Annual milk production per cow also generally increased over the first few years but was relatively stable at about 4,870 $\mathrm{kg}$ of $\mathrm{FPCM} / \mathrm{cow}$ (or $4,200 \mathrm{~L} / \mathrm{cow}$ ) over the last 5 yr. Consequently, annual FPCM/ha showed a small increase in the first 2 yr but was relatively stable at around $14,000 \mathrm{~kg} / \mathrm{ha}$.

The $\mathrm{N}$ fertilizer use on-farm was relatively stable over time at 130 to $140 \mathrm{~kg}$ of N/ha per year, whereas $\mathrm{P}$ fertilizer use trended downward over time (Figure 3 ). The amount of brought-in feed utilized per hectare showed no clear temporal trend, varying between approximately 2.0 and $2.7 \mathrm{t}$ of $\mathrm{DM} /$ ha per year, whereas use of on-farm crop was a minor component of total feed intake (0.7 t of DM/ha per annum; Figure 4$)$. The amount of pasture intake from grazing was estimated to increase during the first $5 \mathrm{yr}$ and then remained at 


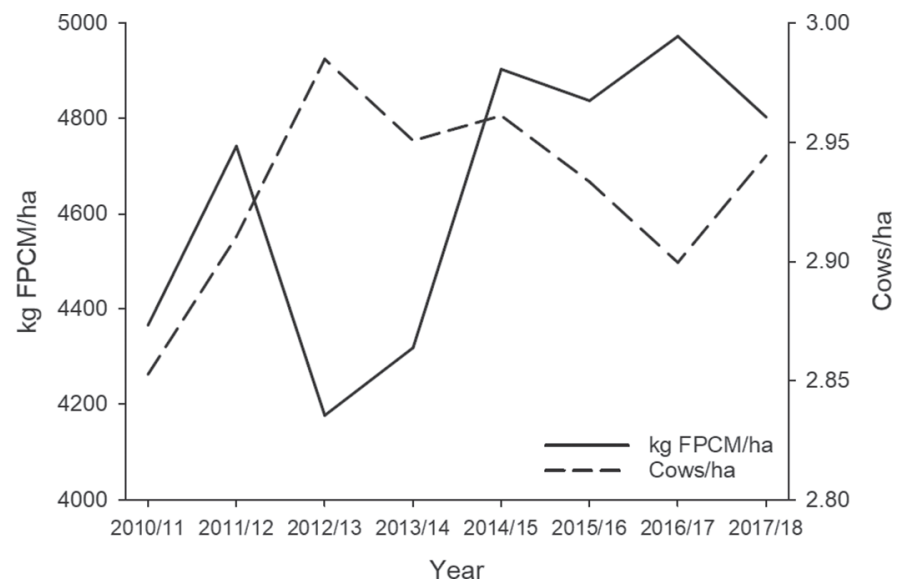

Figure 2. Temporal changes in fat- and protein-corrected milk (FPCM) production per cow and stocking rate on Fonterra's New Zealand average dairy farms.

about $11.7 \mathrm{t}$ of $\mathrm{DM} /$ ha per year. It was least in 2010/11 associated with significant drought across the North Island of NZ, which produced over $60 \%$ of total milk production in NZ.

\section{Regional Variation}

There was only small variation in the average carbon footprint of milk in 2017/18 across the main regions of
NZ (Table 4). It was highest in Northland (which has been consistent over time; Figure 5), associated with a lower stocking rate and per-cow milk production. The other main regional difference is the higher stocking rate and per-cow milk production, greater $\mathrm{N}$ fertilizer use, and widespread irrigation in the Marlborough + Canterbury region compared with all other regions, but its carbon footprint of milk was similar.

Generally greater temporal variation was observed within regions (Figure 5) than for the average of all regions. An example of this was Taranaki in 2017/18 when the carbon footprint was second highest overall and can be attributed to a localized drought.

\section{Effect of Data Source}

All data presented so far have been based on survey farm data collected by DairyNZ and represented 368 farms across NZ (in 2017/18), with weighting across regions according to milk supply to obtain a Fonterra NZ average. Fonterra also collected data in 2017/18 from their individual farmer suppliers and these data (covering the different regions across NZ) from over 7,000 farms were also used for LCA. The average of this farm data and calculated carbon footprint results were similar to that from the DairyBase data for 2017/18. The same carbon footprint result was also obtained

Table 3. Carbon footprint of milk [ $\mathrm{kg}$ of $\mathrm{CO}_{2}$ equivalent (eq) $/ \mathrm{kg}$ of fat- and protein-corrected milk (FPCM); after allocation] for the years $2010 / 11$ to $2017 / 18$ and the contributing sources

\begin{tabular}{|c|c|c|c|c|c|c|c|c|}
\hline Item & $2010 / 11$ & $2011 / 12$ & $2012 / 13$ & $2013 / 14$ & $2014 / 15$ & $2015 / 16$ & $2016 / 17$ & $2017 / 18$ \\
\hline $\mathrm{CH}_{4}$ (total from animals) & 0.559 & 0.551 & 0.557 & 0.543 & 0.541 & 0.542 & 0.531 & 0.539 \\
\hline Cow enteric $\mathrm{CH}_{4}$ & 0.475 & 0.473 & 0.478 & 0.468 & 0.464 & 0.464 & 0.453 & 0.464 \\
\hline Cow fecal $\mathrm{CH}_{4}$ & 0.005 & 0.005 & 0.005 & 0.005 & 0.005 & 0.005 & 0.005 & 0.005 \\
\hline Cow $\mathrm{FDE}^{1} \mathrm{CH}_{4}$ & 0.004 & 0.004 & 0.004 & 0.003 & 0.003 & 0.004 & 0.003 & 0.003 \\
\hline Replacements $\mathrm{CH}_{4}$ & 0.075 & 0.070 & 0.071 & 0.067 & 0.069 & 0.070 & 0.070 & 0.067 \\
\hline $\mathrm{N}_{2} \mathrm{O}$ (animals + on-farm crops) & 0.128 & 0.124 & 0.125 & 0.120 & 0.118 & 0.123 & 0.120 & 0.120 \\
\hline $\mathrm{N}_{2} \mathrm{O}$ from excreta on farm & 0.078 & 0.078 & 0.077 & 0.076 & 0.074 & 0.076 & 0.073 & 0.074 \\
\hline $\mathrm{N}_{2} \mathrm{O}$ from $\mathrm{FDE}$ & 0.002 & 0.002 & 0.002 & 0.002 & 0.002 & 0.002 & 0.002 & 0.002 \\
\hline $\mathrm{N}_{2} \mathrm{O}$ from $\mathrm{N}$ fertilizer on farm & 0.027 & 0.025 & 0.026 & 0.024 & 0.024 & 0.026 & 0.026 & 0.026 \\
\hline $\begin{array}{l}\mathrm{N}_{2} \mathrm{O} \text { from replacements } \\
\text { (excreta and fertilizer off farm) }\end{array}$ & 0.018 & 0.017 & 0.017 & 0.016 & 0.017 & 0.017 & 0.017 & 0.016 \\
\hline $\mathrm{N}_{2} \mathrm{O}$ from crop residues & 0.002 & 0.002 & 0.004 & 0.002 & 0.002 & 0.002 & 0.002 & 0.002 \\
\hline $\mathrm{CO}_{2}(\text { total })^{2}$ & 0.119 & 0.106 & 0.116 & 0.106 & 0.109 & 0.108 & 0.102 & 0.116 \\
\hline $\mathrm{CO}_{2}$ from $\mathrm{N}$ fertilizer & 0.035 & 0.032 & 0.033 & 0.030 & 0.030 & 0.033 & 0.032 & 0.033 \\
\hline $\mathrm{CO}_{2}$ from $\mathrm{P}, \mathrm{K}, \mathrm{S}$ fertilizer & 0.008 & 0.007 & 0.006 & 0.006 & 0.005 & 0.004 & 0.006 & 0.006 \\
\hline $\mathrm{CO}_{2}$ from lime & 0.003 & 0.004 & 0.007 & 0.005 & 0.003 & 0.005 & 0.004 & 0.006 \\
\hline $\mathrm{CO}_{2}$ from electricity & 0.012 & 0.011 & 0.010 & 0.010 & 0.013 & 0.011 & 0.010 & 0.010 \\
\hline $\mathrm{CO}_{2}$ from fuel & 0.004 & 0.004 & 0.004 & 0.004 & 0.004 & 0.004 & 0.004 & 0.004 \\
\hline $\mathrm{CO}_{2}$ from supplementary feed & 0.047 & 0.039 & 0.047 & 0.042 & 0.045 & 0.041 & 0.037 & 0.049 \\
\hline $\begin{array}{l}\mathrm{CO}_{2} \text { from feed for replacements } \\
\text { and cows wintered off farm }\end{array}$ & 0.009 & 0.009 & 0.009 & 0.008 & 0.008 & 0.008 & 0.009 & 0.008 \\
\hline Refrigerant loss in $\mathrm{CO}_{2} \mathrm{eq}$ & 0.001 & 0.001 & 0.001 & 0.001 & 0.001 & 0.001 & 0.001 & 0.001 \\
\hline Total $^{3}$ & 0.806 & 0.781 & 0.798 & 0.770 & 0.768 & 0.773 & 0.753 & 0.776 \\
\hline
\end{tabular}

${ }^{1} \mathrm{FDE}=$ farm dairy effluent.

${ }^{2}$ Includes minor $\mathrm{CH}_{4}$ and $\mathrm{N}_{2} \mathrm{O}$ emissions (especially from brought-in feeds, e.g., $\mathrm{CH}_{4}$ from palm processing and $\mathrm{N}_{2} \mathrm{O}$ from crop residues).

${ }^{3}$ Other miscellaneous contributors (e.g., pesticide production and use, cleaning chemicals) not identified because they sum to $<0.001$. 
when DairyBase data were used to calculate a weighted average based on total NZ milk production across all NZ regions including Westland, which has few Fonterra suppliers (Table 5).

\section{Effect of Cow Productivity (Fonterra Farm Data)}

Data for the average of the lower and upper quartile of Fonterra farms (as described in the previous section) according to the level of FPCM production per cow were analyzed and showed a 15\% lower carbon footprint for the upper quartile (Table 6). This difference was primarily associated with a decrease in $\mathrm{CH}_{4}$ emission intensity. There was also a small decrease in carbon footprint of live weight sold for meat. The difference between quartiles was associated with a $71 \%$ greater milk production per cow for the upper quartile.

\section{Effect of Including Direct Land Use Change}

The direct LUC contribution from plantation forestry estimated to be converted to pasture for dairying equated to $0.13 \mathrm{~kg}$ of $\mathrm{CO}_{2} \mathrm{eq} / \mathrm{kg}$ of $\mathrm{FPCM}$ in 2016/17 (data were unavailable for $2017 / 18$ ). This resulted in the total carbon footprint of milk in 2016/17 increasing from 0.75 to $0.88 \mathrm{~kg}$ of $\mathrm{CO}_{2} \mathrm{eq} / \mathrm{kg}$ of $\mathrm{FPCM}$.

\section{Effect of $\mathrm{N}_{2} \mathrm{O}$ Emission Factors}

Use of the NZ-specific $\mathrm{N}_{2} \mathrm{O}$ EF resulted in the total $\mathrm{N}_{2} \mathrm{O}$ emissions being $59 \%$ lower compared with that calculated using the IPCC default $\mathrm{N}_{2} \mathrm{O}$ EF (Table 7). This resulted in an $18 \%$ lower overall estimate of the carbon footprint of milk. It was associated with a $58 \%$ lower estimate of direct $\mathrm{N}_{2} \mathrm{O}$ emissions due to lower NZ-specific EF. Indirect emissions from leached-N and ammonia- $\mathrm{N}$ were also 77 and $42 \%$ lower, respectively, due to lower NZ-specific N-loss factors.

\section{Effect of GWP Factors}

The carbon footprint of milk was $5 \%$ higher using the latest IPCC (2013) GWP factors compared with that using the IPCC 2007 GWP factors (Table 8). This effect was mainly determined by the $11 \%$ higher $\mathrm{CH}_{4}$ GWP factor due to the dominant contribution of $\mathrm{CH}_{4}$ to the carbon footprint.

\section{DISCUSSION}

\section{Carbon Footprint of Milk}

This study was based on a large data set of NZ dairy farms over multiple years with farm systems involving

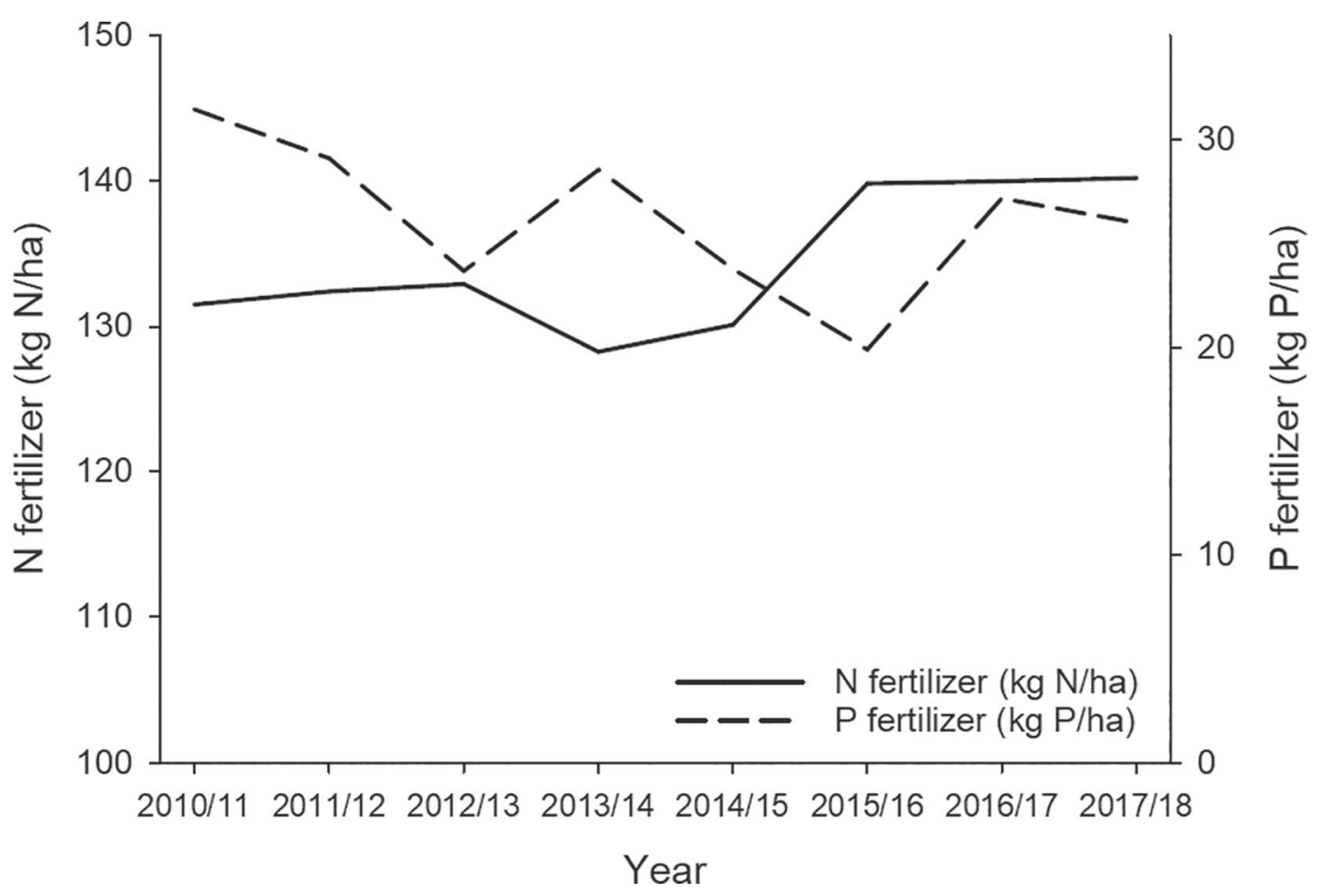

Figure 3. Temporal changes in rate of nitrogen and phosphorus fertilizer on Fonterra's New Zealand average dairy farms (not accounting for fertilizers on off-farm areas such as for grazing replacement animals or growing crops that are brought in to the farm). 
Table 4. Regional variation in carbon footprint of fat- and protein-corrected milk (FPCM) and other key farm, production, and input parameters for the year $2017 / 18$

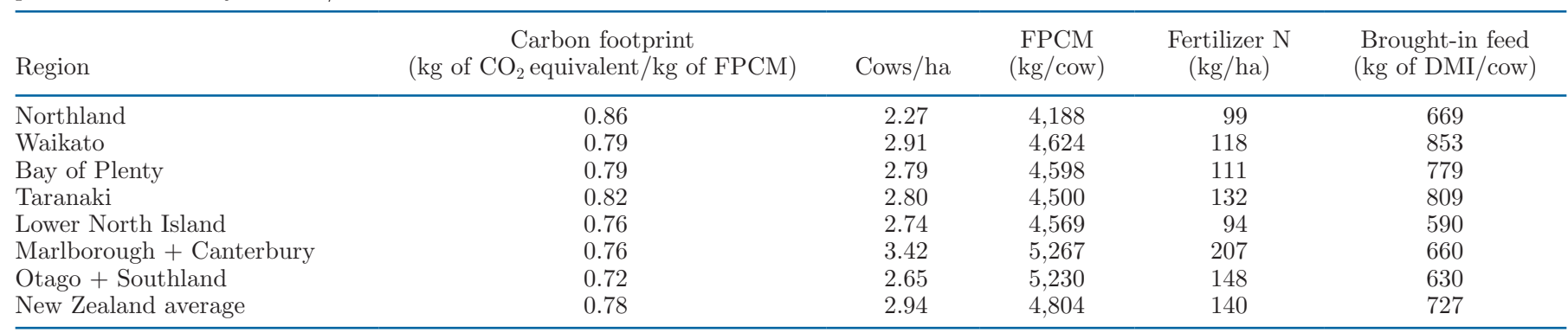

year-round grazing of pastures. The average carbon footprint of NZ milk was $0.75-0.81 \mathrm{~kg}$ of $\mathrm{CO}_{2} \mathrm{eq} / \mathrm{kg}$ of FPCM. This equated to 0.73 to $0.77 \mathrm{~kg}$ of $\mathrm{CO}_{2} \mathrm{eq} / \mathrm{kg}$ of FPCM using the IPCC (2007) GWP, which is at the low end of the average values of 0.8 to $1.3 \mathrm{~kg}$ of $\mathrm{CO}_{2} \mathrm{eq} /$ $\mathrm{kg}$ of FPCM from various studies that covered multiple countries and dairy systems (e.g., O'Brien et al., 2014b; Hietala et al., 2015; Baldini et al., 2017; Lorenz et al., 2019) using the IPCC (2007) GWP.

A review by Lorenz et al. (2019) showed that the carbon footprint value generally decreased with increased milk production per cow and with increased proportion of the diet from pasture. In the Waikato region of NZ, Chobtang et al. (2017) estimated a lower carbon foot- print from dairy farms where almost all of the animal diet was from pasture compared with farms with $70 \%$ from pasture and $30 \%$ from brought-in crop feeds (0.73 vs. $0.86 \mathrm{~kg}$ of $\mathrm{CO}_{2} \mathrm{eq} / \mathrm{kg}$ of $\mathrm{FPCM}$ ).

The current study is one of only a few that have evaluated dairy farms with year-round grazing of pasture as the dominant feed source. Others were single-year studies of 139 dairy farms across Australia (Gollnow et al., 2014) and 24 farms in Uruguay (Lizarralde et al., 2014), which had estimates for the average carbon footprint of milk of 1.1 and $1.0 \mathrm{~kg}$ of $\mathrm{CO}_{2} \mathrm{eq} / \mathrm{kg}$ of FPCM, respectively. Two previous NZ studies of research farm systems or commercial farms from the Waikato region only had values of 0.7 to $0.8 \mathrm{~kg}$ of $\mathrm{CO}_{2} \mathrm{eq} / \mathrm{kg}$ of $\mathrm{FPCM}$

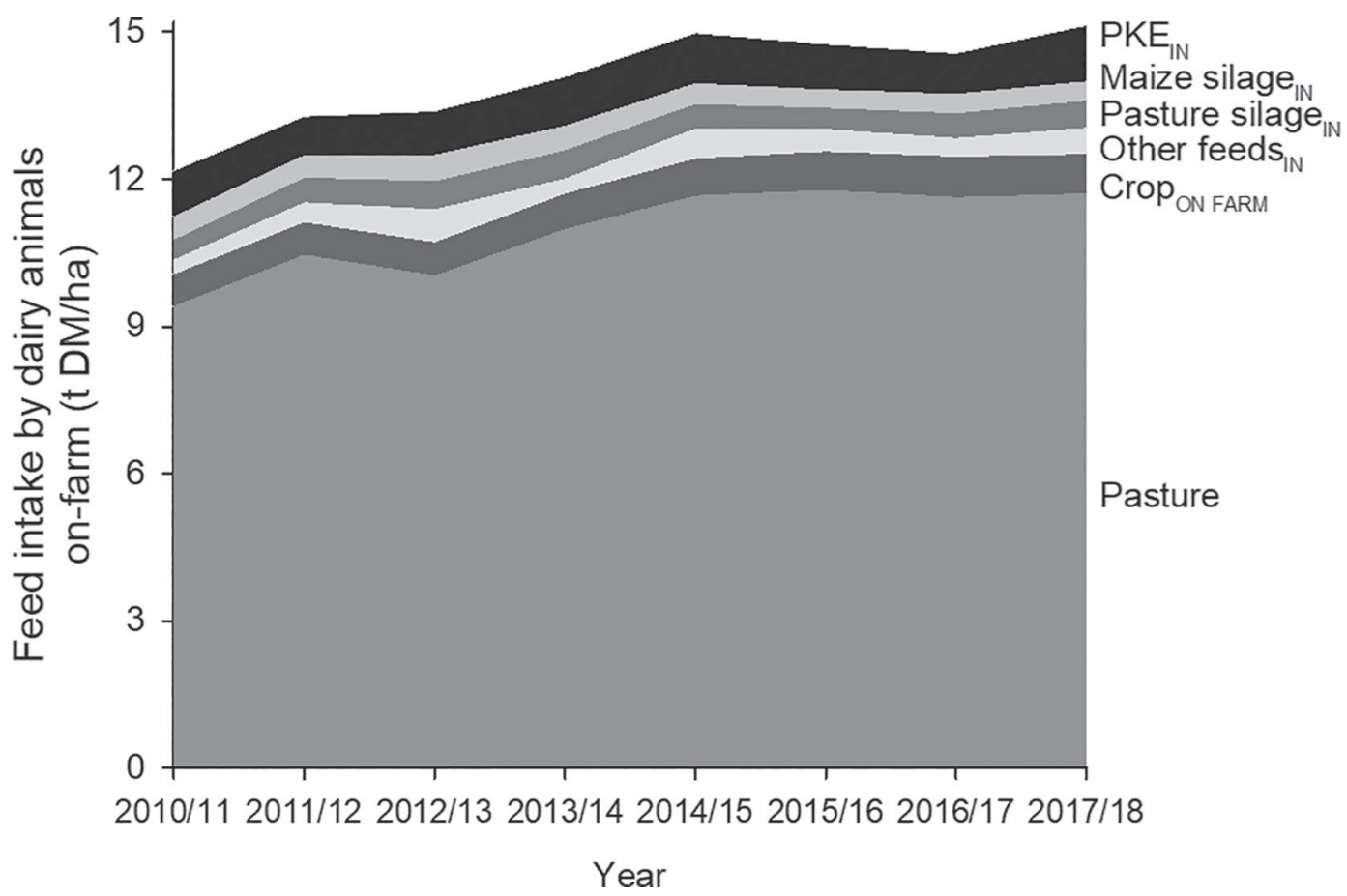

Figure 4. Temporal changes in annual amount of feed consumption on a DM basis from grazing of pasture and crops on-farm, as well as from brought-in feeds (with subscript IN), on Fonterra's New Zealand average dairy farms. Data are expressed on a per-hectare on-farm basis. PKE $=$ palm kernel expeller 


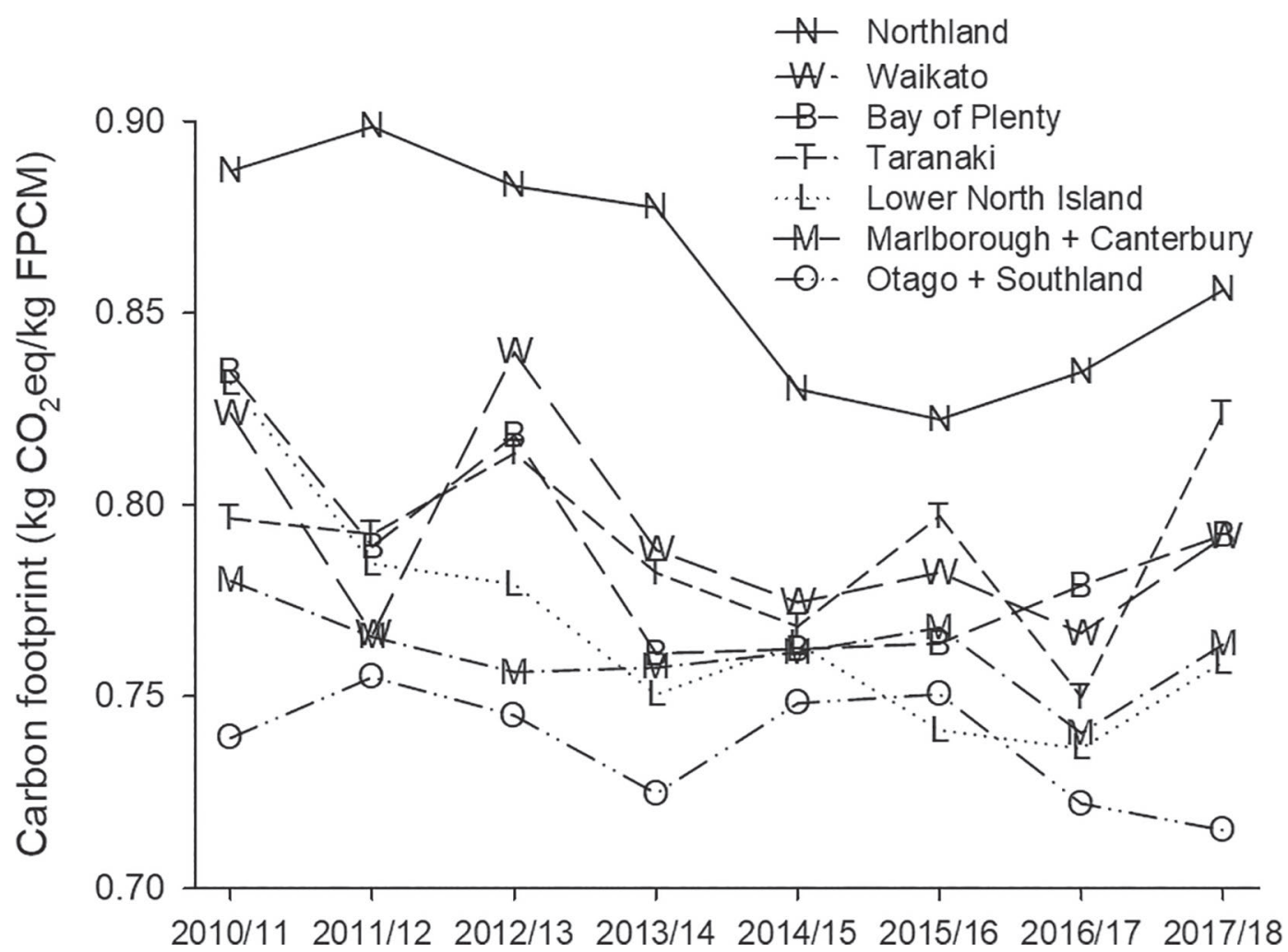

Figure 5. Regional variation in the carbon footprint of New Zealand fat- and protein-corrected milk (FPCM) over time.

(Basset-Mens et al., 2009; Chobtang et al., 2016). Irish dairy farm studies with pasture grazing combined with housing of cows for 3 to 6 mo (requiring brought-in feeds) had average estimates of 1.1 to $1.2 \mathrm{~kg}$ of $\mathrm{CO}_{2} \mathrm{eq} /$ $\mathrm{kg}$ of FPCM (O'Brien et al., 2014a, 2015).

A feature of dairy farms relying on grazing of pasture is the low contribution from $\mathrm{CO}_{2}$ from fossil fuel consumption. In the current study the $\mathrm{CO}_{2}$ emissions from direct fuel consumption on-farm were $<1 \%$ of the carbon footprint and electricity about $1 \%$, whereas in some confinement dairy systems, which require significant fuel use for production and use of crop feeds, it can be over $10 \%$ of the carbon footprint of milk (O'Brien et al., 2014b).

Dairy farms relying on grazing of pasture have a proportionally-high contribution from animal-related $\mathrm{CH}_{4}$ emissions, which constituted $70 \%$ of the carbon footprint of NZ milk, whereas it was $<50 \%$ in some European and US confinement dairy systems (Guerci et al., 2013; Thoma et al., 2013b). A consequence of

Table 5. Effect of farm data source on carbon footprint of fat- and protein-corrected milk (FPCM) and other key farm, production, and input parameters for the year 2017/18

\begin{tabular}{lcc}
\hline Item & DairyBase & Fonterra farm survey \\
\hline No. of farms & 368 & 7,146 \\
Carbon footprint $\left(\mathrm{kg}\right.$ of $\mathrm{CO}_{2} \mathrm{eq} / \mathrm{kg}$ of $\left.\mathrm{FPCM}\right)$ & $0.78(0.78)^{2}$ & 0.78 \\
Stocking rate (cows/ha) & 2.94 & 2.96 \\
Milk production $(\mathrm{kg}$ of $\mathrm{FPCM} / \mathrm{ha})$ & 14,144 & 14,714 \\
Replacement rate & 0.22 & 0.22 \\
Fertilizer N (kg of N/ha) & 140 & 138 \\
Fertilizer P (kg of P/ha) & 26 & 30 \\
Brought-in feed (kg of DMI/cow) & 727 & 801
\end{tabular}

${ }^{1}$ DairyBase refers to a DairyNZ online voluntary database with regional weighting according to milk supply to Fonterra, whereas Fonterra farm survey is for data collected directly from farmers during farm visits. eq $=$ equivalent.

${ }^{2}$ Based on weighted-average milk production for all New Zealand dairy farms (from DairyNZ/LIC, 2018). 
Table 6. Variation in carbon footprint of fat- and protein-corrected milk (FPCM) and other key farm, production, and input parameters for the average and lower and upper quartiles of data for FPCM/cow from the Fonterra farm survey for the year 2017/18

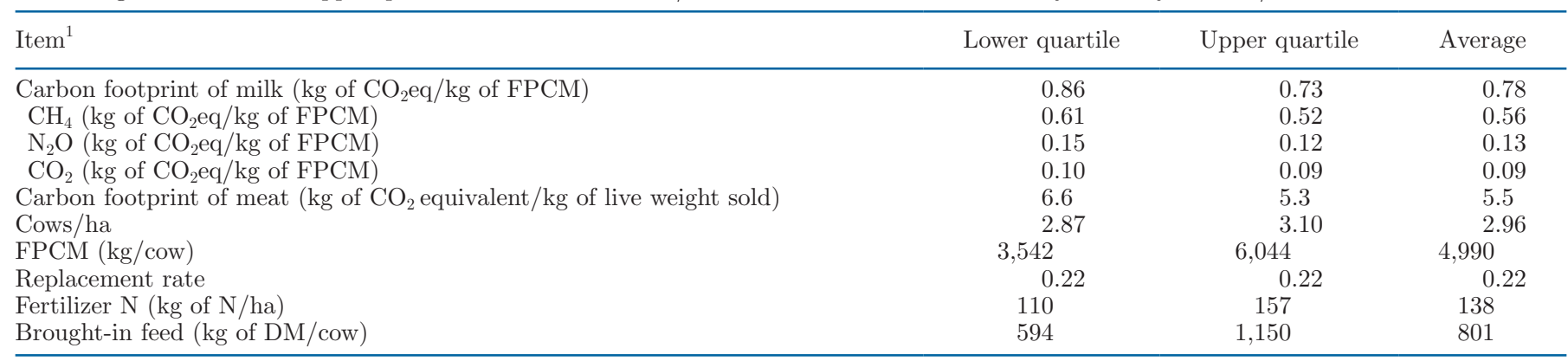

${ }^{1}$ eq $=$ equivalent.

this is that the choice of climate change metrics (GWP characterization factors) have a larger effect on the total calculated $\mathrm{CO}_{2}$ eq emissions from pasture-based systems than intensive crop-based housed cow systems, since $\mathrm{CH}_{4}$ is much more short lived than other GHG (Reisinger et al., 2017; Table 8). In the housed cow systems, crop feed production and manure management are important and contribute mainly to $\mathrm{N}_{2} \mathrm{O}$ and $\mathrm{CO}_{2}$ emissions.

Excreta- $\mathrm{N}$ from grazing animals is relatively high in NZ pasture systems due to the high-quality clover/ grass pastures with a high protein or $\mathrm{N}$ concentration (e.g., approximately $3.7 \% \mathrm{~N}$ ) that greatly exceeds cow requirements. Thus, excess $\mathrm{N}$ is excreted, particularly in urine and is a dominant contributor to ammonia and $\mathrm{N}_{2} \mathrm{O}$ emissions (van der Weerden et al., 2016). Confinement systems provide the opportunity to match feed protein levels with cow requirements by varying the types of feeds used, thereby reducing the amount of $\mathrm{N}$ excreted. However, most (about 95\%) of the excreta$\mathrm{N}$ voided by animals in grazing systems is deposited directly on pastoral soil, and the high OM content and high buffering capacity of most NZ soils limit ammonia loss from excreta (Saggar et al., 2013). In contrast, in confinement systems the excreta is deposited on housing surfaces and is collected into storage facilities, from which ammonia losses can be high (e.g., Sajeev et al., 2018).

Table 7. Carbon footprint of milk and $\mathrm{N}_{2} \mathrm{O}$ contribution $(\mathrm{kg}$ of $\mathrm{CO}_{2}$ equivalent $/ \mathrm{kg}$ of fat- and protein-corrected milk) calculated using New Zealand (NZ)-specific $\mathrm{N}_{2} \mathrm{O}$ emission factors (EF) or the default IPCC (2006) $\mathrm{N}_{2} \mathrm{O}$ emission factors for the year 2017/18

\begin{tabular}{lcc}
\hline Item & $\begin{array}{c}\text { NZ-specific } \\
\text { EF }\end{array}$ & $\begin{array}{c}\text { IPCC default } \\
\text { EF }\end{array}$ \\
\hline Carbon footprint of milk & 0.78 & 0.95 \\
Total $\mathrm{N}_{2} \mathrm{O}$ contribution & 0.12 & 0.29 \\
$\mathrm{~N}_{2} \mathrm{O}$ direct & 0.10 & 0.24 \\
$\mathrm{~N}_{2} \mathrm{O}$ indirect (from ammonia) & 0.01 & 0.02 \\
$\mathrm{~N}_{2} \mathrm{O}$ indirect (from leached $\mathrm{N}$ ) & 0.01 & 0.03 \\
\hline
\end{tabular}

The main contributors to $\mathrm{CO}_{2}$ emissions in this study were from $\mathrm{N}$ fertilizer manufacturing and production of feeds brought in to the farm. Fertilizer $\mathrm{N}$ is predominantly urea and over $60 \%$ of it is imported from Asia or Middle East (the rest made in NZ) and therefore has significant transport emissions, although it is only about one-quarter of that from fertilizer manufacturing (Ledgard et al., 2011). Average rates of $\mathrm{N}$ fertilizer use on pasture in NZ (130-140 kg of N/ha per year) are lower than the average rates used on grassland in Ireland (170-200 kg of N/ha per year; O'Brien et al., 2014a, 2015) but support higher stocking rates and greater pasture intake per hectare in NZ associated with warmer climatic conditions.

The main brought-in feed on NZ dairy farms was PKE, which is used because of its low cost. However, it has a relatively high carbon footprint (e.g., 3 times that of locally grown maize silage per $\mathrm{kg}$ of $\mathrm{DM}$; data in Materials and Methods section). Although some feeds with a very-low carbon footprint (e.g., waste fruit and vegetables of limited availability) are used, there is potential to reduce the carbon footprint of milk by up to $5 \%$ through more selective use of brought-in feeds or by moving further to a pasture-only diet.

A feature of achieving high per-hectare milk production from grazed pasture systems in NZ is the relatively low milk production per cow compared with that from

Table 8. Carbon footprint of Fonterra's New Zealand average milk for the year $2017 / 18$ ( $\mathrm{kg}$ of $\mathrm{CO}_{2}$ equivalent $/ \mathrm{kg}$ of fat- and proteincorrected milk) using IPCC (2007) global warming potential (100 yr; $\mathrm{GWP}_{100}$ ) characterization factors compared with IPCC (2013) $\mathrm{GWP}_{100}$ characterization factors

\begin{tabular}{lcc}
\hline Item & $\begin{array}{r}\text { IPCC 2013 } \\
\text { GWP }\end{array}$ & $\begin{array}{r}\text { IPCC 2007 } \\
\text { GWP }_{100}\end{array}$ \\
\hline $\mathrm{CH}_{4}$ & 0.56 & 0.50 \\
$\mathrm{~N}_{2} \mathrm{O}$ & 0.13 & 0.15 \\
$\mathrm{CO}_{2}$ & 0.09 & 0.09 \\
Other & $<0.01$ & $<0.01$ \\
Total & 0.78 & 0.74 \\
\hline
\end{tabular}


confinement systems (e.g., 4,200 L/cow compared with up to $10,000 \mathrm{~L} / \mathrm{cow}$ ). Various studies have shown that the largest opportunity for reducing the carbon footprint of milk is through increased milk production per cow (e.g., Gerber et al., 2011). Analysis of the average upper and lower quartiles of farms based on $\mathrm{kg}$ of FPCM/cow showed an 18\% lower carbon footprint of milk from farms with $71 \%$ higher $\mathrm{FPCM} /$ cow. In practice, this has been occurring over time in NZ, with the average milk solids (fat + protein) production per cow currently at $368 \mathrm{~kg}$ compared with $259 \mathrm{~kg} /$ cow in 1992/93 (DairyNZ/LIC, 2018). It is also evident in Figure 1 where the FPCM/cow was higher in 2013 to 2018 than in the earlier years. This has been achieved through breeding for higher production-efficiency cows on grazed pastures (Clark et al., 2007). However, a reduction in carbon footprint of milk may not always occur with increased milk production/cow, especially if associated with increased use of crop feeds with high GHG emissions or if it coincides with other loss in productivity [e.g., via reduced replacement rate, fertility, or animal health/welfare (O'Brien et al., 2010)].

An additional feature of the NZ grazing system is the low cow replacement rate at $22 \%$, compared with 30 to $38 \%$ in some high production confinement systems (Flysjö et al., 2011; Lorenz et al., 2019), thereby reducing total animal system feed requirements. The Irish pasture-based dairy system also shows moderate per-cow milk production and a low replacement rate (O'Brien et al., 2014a).

\section{Temporal and Regional Variation in Carbon Footprint of Milk}

This is the first detailed study that has examined the temporal variation in the carbon footprint of milk on an annual basis over several years. Overall it showed a trend $\left(\mathrm{R}^{2}=0.53, P<0.05\right)$ for a decrease in carbon footprint of milk over the $8 \mathrm{yr}$ of assessment, although differences were small. This coincided with a trend for improved milk production per cow over time.

In view of the reliance of the NZ dairy sector on pasture as the main feed source, it would be expected to show greater annual variability in production and carbon footprint than for confinement systems where crop feeds can be sourced from a wider geographic spread. However, limited temporal variation was evident in the annual carbon footprint of milk, which can be associated in part with the even rainfall and temperate climate across much of NZ. Nevertheless, the carbon footprint of milk was higher in early years of this study, which was partly influenced by relatively widespread drought in 2010/11, leading to reduced pasture production, animal intake, and per-cow production.
Relatively little temporal variation was observed in other NZ average farm inputs affecting feed supply, being $\mathrm{N}$ fertilizer rate and level of brought-in feeds. However, the latter showed some variation between years presumably partly reflecting the need to meet variation in overall feed requirements.

Regional variation in carbon footprint of milk was also relatively small, albeit greater than for the NZ average. This occurred despite some relatively large production system differences between regions. For example, in Canterbury the per-hectare production was high due to a high stocking rate, higher per cow production, use of irrigation, and greater fertilizer- $\mathrm{N}$ inputs. This indicates that benefits from higher per-cow production in reducing GHG emission intensity were countered by greater emissions from use of more farm inputs. The highest carbon footprint of milk was in Northland, which can be linked to its lower productivity due to greater climatic variability (only subtropical region in NZ, with dry summers) and soil limitations on pasture production, but still with similar farm inputs per hectare to that in other regions. One example of regional variation was the Taranaki region, which usually is in the middle of the range in carbon footprint of milk of all regions, but in 2017/18 it had the second-highest carbon footprint due to localized drought, which was associated with increased use of $\mathrm{N}$ fertilizer (to grow more feed after the drought) and brought-in feed relative to that in previous years. In the United States, Thoma et al. (2013b) showed some regional variation in the carbon footprint of milk from housed cow systems but it was mainly due to different farm practices between regions (e.g., being greater in a region where manure management involved anaerobic lagoons with high associated $\mathrm{CH}_{4}$ emissions).

\section{Methodology Effects}

A range of methodological aspects can potentially influence the results from carbon footprint assessment. These include factors related to methodology and data representativeness.

The calculation procedures used are critical to application of GHG methodology. To standardize this and to increase the ability to compare results across different studies, a range of guidelines have been established [e.g., IDF (2015) and FAO (2016)]. Most focus on use of tier-2 IPCC-based activity and EF. While IPCC (2006) provided default values, all guidelines refer to the importance of using validated country-specific factors. For livestock products the factors related to animal $\mathrm{CH}_{4}$ and excreta $\mathrm{N}_{2} \mathrm{O}$ are most important because of their relatively large contribution to the carbon footprint. In this study, the enteric $\mathrm{CH}_{4} \mathrm{EF}$ used was based on the 
IPCC default of $6.5 \%$ of energy intake, in common with most published studies.

The NZ-specific factors for excreta $\mathrm{N}_{2} \mathrm{O}$ emissions from the NZ GHG Inventory (MfE, 2018) were used in this study and had a significant effect on results. Sensitivity analysis showed that the effect of this was to estimate an $18 \%$ lower carbon footprint for milk than if the IPCC default $\mathrm{N}_{2} \mathrm{O}$ activity and $\mathrm{EF}$ had been used (Table 5). This was mainly determined by lower direct $\mathrm{EF}$ for $\mathrm{N}_{2} \mathrm{O}-\mathrm{N}$ from animal urine and dung (1.0 and $0.25 \%$, respectively, compared with $2 \%$ IPCC default). These factors were the result of a comprehensive series of research trials across NZ (e.g., 71 trials for cow urine) where direct $\mathrm{N}_{2} \mathrm{O}$ emissions were measured (van der Weerden et al., 2011; Kelliher et al., 2014). One likely factor of importance is the dominance of freedraining soils across almost all dairying regions of NZ, thereby restricting likelihood of anaerobic conditions in soil (Luo et al., 2010). Similarly, a range of NZ field trials have defined average EF for manure and urea fertilizer applied to pasture soil (van der Weerden et al., 2016) and these have been incorporated into the NZ GHG Inventory and applied in this study.

Few studies have accounted for all components of direct LUC in determining the carbon footprint of milk, often assuming stable land use. This study included analysis to estimate the potential contribution for land that had been converted from exotic forestry (mainly plantation pine) to pasture and used for dairying during the past $20 \mathrm{yr}$. This contribution from direct LUC was estimated at the equivalent of $0.13 \mathrm{~kg}$ of $\mathrm{CO}_{2} \mathrm{eq} /$ $\mathrm{kg}$ of FPCM (in 2016/17). In practice, most estimates of direct LUC are based on changes in land use from national statistics [e.g., as used for LUC for PKE using the method of Blonk (2017)]. If the LUC from forest to dairying had been based on NZ statistics on the areas under different land uses over the past 2 decades, it would have produced a nil LUC value. This is because between 1990 and 2016 there was a national change in land use representing a decrease in grassland area of $-3.7 \%$ ( $-566,000 \mathrm{ha})$, whereas there was an increase in the area under forest of $+5.2 \%$ (native and planted; +490,000 ha; MfE, 2018). Although changes in LUC are important to be accounted for in national inventories, they are less relevant when assessing system efficiency and carbon footprints at the farm scale.

Representativeness of data used for carbon footprint analysis is critical. Most results and farm data presented here were from DairyNZ's DairyBase covering 368 farms across NZ and were similar (within 10\%; Table 5 ) to those obtained based on data collected directly from 7,146 NZ suppliers to Fonterra. These 2 data sets also showed the same carbon footprint to that using DairyBase data for milk weighted for the average total distribution of milk production across NZ. These comparisons indicate that the data entered into DairyBase by farmers on-line was representative of the dairy farm population.

An important aspect of dairy cow milk production is the relatively high protein and fat content, as well as other important constituents such as relatively high micronutrient and digestible indispensable AA contents (Loveday, 2019). Thus, it is important that appropriate functional units are used when determining the carbon footprint of milk and other foods. For dairy products, the use of FPCM is recommended (IDF, 2015), which accounts for total protein and fat content. This is important for comparison of different dairy production systems. The NZ dairy system is dominated by kiwicross cows with a significant Jersey component, resulting in relatively high protein and fat concentrations [e.g., being up to $31 \%$ higher than that for US dairy cows (Capper et al., 2009)].

\section{CONCLUSIONS}

This study showed a small decrease in the carbon footprint of NZ milk over 8 yr from 2010/11 to 2017/18 and with limited temporal variation, despite reliance on year-round grazing of pastures with production prone to climatic variability. In the early years of wide-spread drought, the carbon footprint of milk was approximately $5 \%$ higher than for later years, associated with lower pasture intake by cows and lower per-cow production. This was also evident with localized drought in the Taranaki region in 2017/18 (approximately 7\% higher carbon footprint), where external inputs of fertilizer $\mathrm{N}$ and brought-in feeds were increased to limit effects on milk production. A key factor determining the relatively low carbon footprint of NZ milk compared with other published studies was the use of year-round grazing of high-quality perennial pasture, with low use of feed from crops and associated GHG emissions from crop residues and fossil energy use for production and feeding of crops. Relatively low cow replacement rate is another contributing factor. Low $\mathrm{N}_{2} \mathrm{O}$ emissions from excreta, manure, and fertilizer using EF validated from considerable field research also contributed to the low carbon footprint values compared with that in some other studies that used default IPCC EF. Farms in the upper quartile of the national data based on milk production per cow had a $15 \%$ lower carbon footprint than those in the lower quartile and showed the potential for carbon footprint reduction with management. This could be further decreased by reducing use of high GHG-emission inputs of brought-in feeds (particularly PKE) and optimizing use of fertilizer N. 


\section{ACKNOWLEDGMENTS}

We thank DairyNZ (Hamilton, NZ) for supply of farm data from DairyBase and the many farmers who provided data from their farms for use in this research. We also thank Nick Sneddon (Fonterra, Hamilton) for data summary and analysis for the Fonterra farms.

\section{REFERENCES}

Baldini, C., D. Gardoni, and M. Guarino. 2017. A critical review of the recent evolution of Life Cycle Assessment applied to milk production. J. Clean. Prod. 140:421-435.

Basset-Mens, C., S. Ledgard, and M. Boyes. 2009. Eco-efficiency of intensification scenarios for milk production in New Zealand. Ecol. Econ. 68:1615-1625.

Beef+LambNZ. 2018. Sheep and beef farm survey: Data and tools. On farm data \& industry production. Accessed Jun. 15, 2019. https:/ /beeflambnz.com/data-tools/sheep-beef-farm-survey.

Benbrook, C. M., D. R. Davis, B. J. Heins, M. A. Latif, C. Leifert, L. Peterman, G. Butler, O. Faergeman, S. Abel-Caines, and M. Baranski. 2018. Enhancing the fatty acid profile of milk through forage-based rations, with nutrition modeling of diet outcomes. Food Sci. Nutr. 6:681-700.

Blonk, H. 2017. Direct land use change assessment tool. Blonk consultants. Version 2017-2. Vol. 2019.

Capper, J. L., R. A. Cady, and D. E. Bauman. 2009. The environmental impact of dairy production: 1944 compared with 2007. J. Anim. Sci. 87:2160-2167.

Chobtang, J., S. F. Ledgard, S. J. McLaren, and D. J. Donaghy. 2017. Life cycle environmental impacts of high and low intensification pasture-based milk production systems: A case study of the Waikato region. New Zealand. J. Clean. Prod. 140:664-674.

Chobtang, J., S. F. Ledgard, S. J. McLaren, M. Zonderland-Thomassen, and D. J. Donaghy. 2016. Appraisal of environmental profiles of pasture-based milk production: A case study of dairy farms in the Waikato region, New Zealand. Int. J. Life Cycle Assess. $21: 311-325$.

Clark, D. A., J. R. Caradus, R. M. Monaghan, P. Sharp, and B. S. Thorrold. 2007. Issues and options for future dairy farming in New Zealand. N. Z. J. Agric. Res. 50:203-221.

CSIRO. 1990. Feeding standards for Australian Livestock: Ruminants. Australian Agricultural Council. Ruminants Sub Committee. CSIRO publications, Australia.

DairyNZ. 2017. Facts and Figures: A quick reference guide for New Zealand dairy farmers. in https://www.dairynz.co.nz/media/ $5789569 /$ facts and figures web 220617.pdf. Vol. 2019

DairyNZ/LIC. 2017-18. 2018. New Zealand Dairy Statistics 2019:L (I. C. L. D. Limited.).

de Klein, C. A., L. Barton, R. R. Sherlock, Z. Li, and R. P. Littlejohn. 2003. Estimating a nitrous oxide emission factor for animal urine from some New Zealand pastoral soils. Soil Res. 41:381-399.

EDA. 2018. Product environmental footprint category rules for dairy products. Final version for EC. Prepared by technical secretariat for European Dairy Association, Belgium.

Ertl, P., W. Knaus, and W. Zollitsch. 2016. An approach to including protein quality when assessing the net contribution of livestock to human food supply. Animal 10:1883-1889.

FAO. 2016. Environmental performance of large ruminant supply chains: Guidelines for assessment. Version 1. Livestock Environmental Assessment and Performance Partnership. FAO, Rome, Italy.

FAO. 2019. Gateway to dairy production and products. Vol. 2019 Food and Agriculture Organization of the United Nations, Rome, Italy.

Flysjö, A., M. Henriksson, C. Cederberg, S. Ledgard, and J.-E. Englund. 2011. The impact of various parameters on the carbon footprint of milk production in New Zealand and Sweden. Agric. Syst. 104:459-469.
Foroutan, A., A. C. Guo, R. Vazquez-Fresno, M. Lipfert, L. Zhang, J. Zheng, H. Badran, Z. Budinski, R. Mandal, B. N. Ametaj, and D. S. Wishart. 2019. Chemical composition of commercial cow's milk. J. Agric. Food Chem. 67:4897-4914.

Gerber, P., T. Vellinga, C. Opio, and H. Steinfeld. 2011. Productivity gains and greenhouse gas emissions intensity in dairy systems. Livest. Sci. 139:100-108.

Gollnow, S., S. Lundie, A. D. Moore, J. McLaren, N. van Buuren, P. Stahle, K. Christie, D. Thylmann, and T. Rehl. 2014. Carbon footprint of milk production from dairy cows in Australia. Int. Dairy J. 37:31-38.

Guerci, M., M. T. Knudsen, L. Bava, M. Zucali, P. Schönbach, and T. Kristensen. 2013. Parameters affecting the environmental impact of a range of dairy farming systems in Denmark, Germany and Italy. J. Clean. Prod. 54:133-141.

Hietala, S., L. Smith, M. T. Knudsen, S. Kurppa, S. Padel, and J. E. Hermansen. 2015. Carbon footprints of organic dairying in six European countries - Real farm data analysis. Org. Agric. 5:91-100.

Hill, J. P. 2017. Assessing the overall impact of the dairy sector. Pages 291-314 in Achieving Sustainable Production of Milk. Vol. 2. N. van Belzen, ed. Burleigh Dodds Science Publishing Limited, Cambridge, United Kingdom.

Holmes, C., I. Brookes, D. Garrick, D. Mackenzie, T. Parkinson, and G. Wilson. 2002. Feeding and management of heifer replacements. Milk Production from Pasture. Massey University Press, Palmerston North, New Zealand.

IDF. 2015. A common carbon footprint approach for the dairy sector: The IDF Guide to Standard Life Cycle Assessment Methodology. In Bulletin of the International Dairy Federation 479/2015. Brussels, Belgium.

IPCC. 2006. IPCC Guidelines for National Greenhouse Gas Inventories: Volume 4: Agriculture, Forestry and Other Land Use. Intergovernmental Panel on Climate Change, Paris, France.

IPCC. 2007. Changes in atmospheric constituents and in radiative forcing. In Climate Change 2007: The Physical Science Basis. Contribution of Working Group I to the Fourth Assessment Report of the Intergovernmental Panel on Climate Change. S. Solomon, D. Qin, M. Manning, Z. Chen, M. Marquis, K. B. Averyt, M. Tignor, and H. L. Miller. ed. Cambridge University Press, Cambridge, United Kingdom.

IPCC. 2013. Climate Change 2013: The Physical Science Basis. T. F. Stocker, D. Qin, G.-K. Plattner, M. Tignor, S. K. Allen, J Boschung, A. Nauels, Y. Xia, V. Bex, and P. M. Midgley, ed. Cambridge University Press, Cambridge, United Kingdom.

ISO. 2006. Environmental management-Life cycle assessment: Requirements and guidelines. ISO 14044:2006. International Organization for Standardization, European Committee for Standardization, Brussels, Belgium.

Kelliher, F. M., N. Cox, T. J. van der Weerden, C. A. M. de Klein, J. Luo, K. C. Cameron, H. J. Di, D. Giltrap, and G. Rys. 2014. Statistical analysis of nitrous oxide emission factors from pastoral agriculture field trials conducted in New Zealand. Environ. Pollut. 186:63-66

Ledgard, S., and S. Falconer. 2015. Total greenhouse gas emissions from farm systems with increasing use of supplementary feeds across different regions of New Zealand. Report to MPI. RE500/2015/033. AgResearch, Hamilton, New Zealand.

Ledgard, S. F., M. Boyes, and F. Brentrup. 2011. Life cycle assessment of local and imported fertilisers used on New Zealand farms. Pages 1-13 in Adding to the Knowledge Base for the Nutrient Manager. L. D. Currie and C. L. Christensen, ed. Fertilizer and Lime Research Centre, Massey University, Palmerston North, New Zealand.

Lizarralde, C., V. Picasso, C. A. Rotz, M. Cadenazzi, and L. Astigarraga. 2014. Practices to reduce milk carbon footprint on grazing dairy farms in southern Uruguay: Case studies. Sustain. Agric. Res. 3:1-15.

Lorenz, H., T. Reinsch, S. Hess, and F. Taube. 2019. Is low-input dairy farming more climate friendly? A meta-analysis of the carbon footprints of different production systems. J. Clean. Prod. 211:161-170. 
Loveday, S. M. 2019. Food proteins: Technological, nutritional, and sustainability attributes of traditional and emerging proteins. Annu. Rev. Food Sci. Technol. 10:311-339.

Luo, J., C. A. M. de Klein, S. F. Ledgard, and S. Saggar. 2010. Management options to reduce nitrous oxide emissions from intensively grazed pastures: A review. Agric. Ecosyst. Environ. 136:282-291.

Manley, B. 2017. Deforestation intentions survey. In MPI Technical Paper No: 2018/16. Ministry for Primary Industries, Wellington, New Zealand.

MBIE. 2018. Energy in New Zealand 18. Ministry for Business, Innovation and Employment, New Zealand Government, Wellington, New Zealand.

MfE. 2018. New Zealand's Greenhouse Gas Inventory 1990-2015: NZ Ministry of the Environment report. Wellington, New Zealand. Accessed Jun. 15, 2019. http://www.mfe.govt.nz/climate-change/ reporting-greenhouse-gas-emissions/nzs-greenhouse-gas-inventory.

O'Brien, D., P. Brennan, J. Humphreys, E. Ruane, and L. Shalloo. 2014a. An appraisal of carbon footprint of milk from commercial grass-based dairy farms in Ireland according to a certified life cycle assessment methodology. Int. J. Life Cycle Assess. 19:1469-1481.

O'Brien, D., J. Capper, P. Garnsworthy, C. Grainger, and L. Shalloo. 2014b. A case study of the carbon footprint of milk from highperforming confinement and grass-based dairy farms. J. Dairy Sci. 97:1835-1851.

O'Brien, D., T. Hennessy, B. Moran, and L. Shalloo. 2015. Relating the carbon footprint of milk from Irish dairy farms to economic performance. J. Dairy Sci. 98:7394-7407.

O'Brien, D., L. Shalloo, C. Grainger, F. Buckley, B. Horan, and M. Wallace. 2010. The influence of strain of Holstein-Friesian cow and feeding system on greenhouse gas emissions from pastoral dairy farms. J. Dairy Sci. 93:3390-3402.

PAS2050. 2011. Specification for the assessment of the life cycle greenhouse gas emissions of goods and services. British Standards Institution, London, United Kingdom.

Reisinger, A., S. F. Ledgard, and S. J. Falconer. 2017. Sensitivity of the carbon footprint of New Zealand milk to greenhouse gas metrics. Ecol. Indic. 81:74-82.

Renouf, M. A., M. K. Wegener, and R. J. Pagan. 2010. Life cycle assessment of Australian sugarcane production with a focus on sugarcane growing. Int. J. Life Cycle Assess. 15:927-937.

Saggar, S., J. Singh, D. L. Giltrap, M. Zaman, J. Luo, M. Rollo, D. G. Kim, G. Rys, and T. J. van der Weerden. 2013. Quantification of reductions in ammonia emissions from fertiliser urea and animal urine in grazed pastures with urease inhibitors for agriculture inventory: New Zealand as a case study. Sci. Total Environ. 465:136-146.

Sajeev, M., E. Purath, W. Winiwarter, and B. Amon. 2018. Greenhouse gas and ammonia emissions from different stages of liquid manure management chains: Abatement options and emission interactions. J. Environ. Qual. 47:30-41.
Schmidt, J. H. 2007. Life cycle assessment of rapeseed oil and palm oil. Part 3: Life cycle inventory of rapeseed oil and palm oil. PhD thesis. Department of Development and Planning, Aalborg University, Denmark.

Sims, R. E. H., N. P. Jayamah, J. Barrie, K. Hartman, and S. Berndt. 2005. Reducing economic and climate change impacts of dairy farm energy end use. In Report prepared for Dairy Insight, Palmerston North, New Zealand.

Stats, N. Z. 2019. Harmonized trade-Imports, exports, and re-exports. StatisticsNZ. Infoshare. Accessed Jun. 15, 2019. http://archive .stats.govt.nz/infoshare/TradeVariables.aspx?DataType=TIM.

Stylianou, K. S., M. C. Heller, V. L. Fulgoni, A. S. Ernstoff, G. A. Keoleian, and O. Jolliet. 2016. A life cycle assessment framework combining nutritional and environmental health impacts of diet: A case study on milk. Int. J. Life Cycle Assess. 21:734-746.

Thoma, G., J. Popp, D. Nutter, D. Shonnard, R. Ulrich, M. Matlock, D. S. Kim, Z. Neiderman, N. Kemper, C. East, and F. Adom. 2013. Greenhouse gas emissions from milk production and consumption in the United States: A cradle-to-grave life cycle assessment circa 2008. Int. Dairy J. 31:S3-S14.

Thoma, G., J. Popp, D. Shonnard, D. Nutter, M. Matlock, R. Ulrich, W. Kellogg, D. S. Kim, Z. Neiderman, N. Kemper, F. Adom, and C. East. 2013b. Regional analysis of greenhouse gas emissions from USA dairy farms: A cradle to farm-gate assessment of the American dairy industry circa 2008. Int. Dairy J. 31:S29-S40.

van der Weerden, T. J., N. Cox, J. Luo, H. J. Di, A. Podolyan, R. L. Phillips, S. Saggar, C. A. M. de Klein, P. Ettema, and G. Rys. 2016. Refining the New Zealand nitrous oxide emission factor for urea fertiliser and farm dairy effluent. Agric. Ecosyst. Environ. 222:133-137.

van der Weerden, T. J., J. Luo, C. A. M. de Klein, C. J. Hoogendoorn, R. P. Littlejohn, and G. J. Rys. 2011. Disaggregating nitrous oxide emission factors for ruminant urine and dung deposited onto pastoral soils. Agric. Ecosyst. Environ. 141:426-436.

Vermeulen, S. J., B. M. Campbell, and J. S. I. Ingram. 2012. Climate change and food systems. Annu. Rev. Environ. Resour. 37:195-222.

Wells, C. 2001. Total energy indicators of agricultural sustainability: Dairy farming case study final report. in Report to Ministry of Agriculture and Forestry, Wellington, New Zealand Dept. of Physics, University of Otago, New Zealand.

Wernet, G., C. Bauer, B. Steubing, J. Reinhard, E. Moreno-Ruiz, and B. Weidema. 2016. The ecoinvent database version 3 (part I): Overview and methodology. Int. J. Life Cycle Assess. 21:1218-1230.

\section{ORCIDS}

S. F. Ledgard (๑) https://orcid.org/0000-0002-6623-8172

S. J. Falconer ๑ https://orcid.org/0000-0003-2860-3842

J. P. Hill ৫ https://orcid.org/0000-0003-4196-6541 
APPENDIX

Appendix Table A1. Summary of emission factors (EF) used in the life cycle assessment of the carbon footprint of milk covering off-farm and background inputs in grams of $\mathrm{CO}_{2}$ equivalent (eq) $)^{1}$

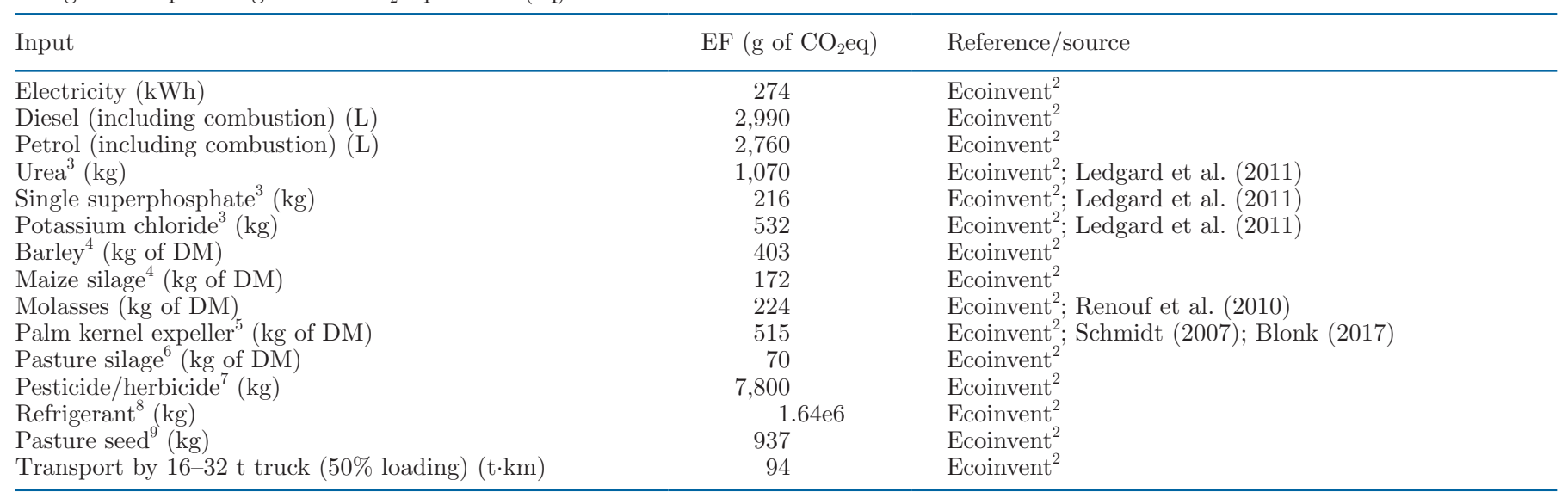

${ }^{1} \mathrm{CO}_{2}=1$; biogenic $\mathrm{CH}_{4}=27.75$; fossil $\mathrm{CH}_{4}=30.5 ; \mathrm{N}_{2} \mathrm{O}=265$ (IPCC, 2013).

${ }^{2}$ Ecoinvent database version 3.4 (Wernet et al., 2016), accounting for New Zealand (NZ)-specific processes.

${ }^{3}$ For fertilizers used in NZ accounting for local (where relevant) and imported sources, transport of constituents, manufacturing (cradle-to-NZ port or cradle-to-manufacturing gate).

${ }^{4}$ Based on NZ-specific yield and published data on inputs and production activities (e.g., cultivation, pesticides, herbicides, fertilization, harvesting), including $\mathrm{N}_{2} \mathrm{O}$ emissions from crop residues. Represents the cradle-to-crop-gate stage.

${ }^{5}$ Based on detailed data from Schmidt (2007), land use change, economic allocation of co-products, and transportation to an average NZ port.

${ }^{6}$ Assumed to be from pasture surplus on farmer-owned land, with low input of fertilizers and accounts for all silage-making activities.

${ }^{7}$ Based on a mix of products used.

${ }^{8}$ Using R134a as proxy for manufacturing.

${ }^{9}$ Based on NZ-produced ryegrass seed, accounting for all inputs; used as proxy for all pasture and forage crop seeds. 